\title{
Urban agriculture in Dar es Salaam: a dream or reality?
}

\author{
H. S. Mkwela \\ Norwegian University of Science and Technology (NTNU), Norway
}

\begin{abstract}
The paper focuses on the policy issues concerning urban agriculture (UA) in Dar es Salaam city. It argues that the process of formalisation and/or including UA in the city master plan takes longer than expected despite efforts by local and international stakeholders including the UN Habitat and United National Environmental Program (UNEP). The two agents jointly launched the Sustainable Dar es Salaam City Project (SDCP) in 1992 which became operational in 1993. The project idea was to make Dar es Salaam one of exemplary sustainable cities in Africa. Urban agriculture was identified as one of the priority for the Project; because a sustainable city should be able to feed its residents by using local resources. By the time the project was completed in 2003, still, there was no clear UA policy in the country. In support of UN Habitat and UNEP initiatives for a Sustainable Dar es Salaam City Project, national and international funded UA development projects have been implemented at different times and scales. One of these programmes is the on-going Sustainable Cities International Network-Africa Programme (SCINAP) which is aimed at promoting legitimization of UA in the city. These projects have had a number of proposals concerning inclusion of UA in the city's master plan which are yet to be implemented by the authorities. These delays have left the hapless urban farmers with no alternative but to invade institutional and hazardous land leading to insecurity of tenure and environmental degradation. The paper is aimed at identifying and analysing the sources of delay in formalisation and inclusion of UA in the master plan. It is based on the in-depth literature and analysis of the published works, policies related to UA and official reports from the government of Tanzania. It would appear from the gathered evidence that among other barriers for the timely formalisation and inclusion of UA in the master plan in Dar es Salaam city is related to urban authorities' perceptions of the activity. Keywords: urban agriculture (UA), sustainable city, Sustainable Dar es Salaam Project, UA policy, UA dream, UA reality.
\end{abstract}




\section{Introduction}

Urban Agriculture (UA) is regarded as one of the fastest growing employment and income generation industries in most developing countries (Mougeot [1]). The Town and Country Planning (Urban Farming) Regulations (1992) defines Urban farming as 'the carrying out of plant and animal husbandry activities within statutory township boundaries as provided in the schedule'. The schedule defines six (6) areas to fall within the UA category ranging from cultivation of crops to serpentaria and forestry and rearing of animals. In Mougeot's [1] view, UA is often located within (intra-urban) or on the fringe (peri-urban) of a town, an urban Centre, a city or metropolis, which grows or raises, processes and distributes a diversity of food and non-food products, (re-) using mainly human and material resources, inputs and services found in and around that urban area, and in turn supplying human and material resources, outputs and services largely to that urban area. Earlier on, Sawio [2] defined UA in Dar es Salaam as the carrying out of farming activities in the built-up and peri-urban areas, where un built land is available, as well as keeping livestock such as dairy cattle, goats, sheep, pigs and fowl. While the first definition is more inclined to purportedly allowable activities that are likely to take place within the defined boundaries, the second and third definitions covers the actual activities that are taking place within townships both urban and peri-urban areas. In this study UA is taken to mean the practice of agricultural activities in the city and its surroundings.

The dream of making Dar es Salaam a sustainable city through the formalisation and managing of agricultural activities seems to be contrary to what is taking place on the ground i.e. the reality. The dream can be traced back from 1992 when UN Habitat and United National Environmental Program (UNEP) introduced the Sustainable Dar es Salaam Project (SDP); the project took off in November 1993 (Mwalukasa [3]). Among other environmental concerns, UA was identified as one of the major environmental issues in the city which needed special attention [3-5]. The project had a responsibility to develop a new Strategic Urban Development Plan (SUDP) for integrating UA into the city management plans [5]. In this respect, a special working group for UA was formed aiming at promoting sustainable UA. By the time the project was completed in 2003, there was no clear urban agriculture policy and UA was not included in the City's Master Plan. It would appear that this dream has not been realized (Mkwela and Banyani [6]).

The reality surrounding UA activities in Dar es Salaam is contrary to the sustainability dream initiated by the SDP and advocated by Sustainable Cities International Network-Africa programme (SCINAP). To-date, UA is regarded as an informal activity; existing without proper plans, designated areas or a guiding policy. UA has been subjected to criticisms from planners, policy makers and researchers. A vivid example is a paper by Mlozi [7] in which UA has been linked to severe health threats, environmental, social and security concerns. Considering this view, UA has more sustainability problems than benefits. Due to the overriding criticisms and negative attitude, UA has not gained a place in the master plan nor in the hearts of the city planners and decision makers 
(Schmidt [8]). As a consequence, farmers face issues related to land access, tenure and security. The National Samples Census (URT [9]) has shown that only $5 \%$ of the estimated 36,551 farmers surveyed in Dar es Salaam have certificate of ownership. The remaining 95\% tend to own land through customary law, rented, borrowed, shared or purchased from other inferior right holders. Agricultural activities in the city are subjects of occasional abuse by the authorities which can take the form of crops destruction and/or evacuation.

The paper is aimed at identifying and analysing the sources of delay in inclusion of UA in the master plan and formulation of the policy guiding UA activities in Dar es Salaam City while taking into consideration of the questions in the paragraph below. It focuses on the policy issues concerning Urban Agriculture (UA) in Dar es Salaam city but while doing so it also makes reference to published UA research works and official reports. In the current situation, it is not very clear what is guiding UA activities in the city due to varieties of policies and other instruments. It is also not clear whether UA is practically accepted or not despite the fact that donors and international researchers have worked for years to outline the guidelines for UA in Dar es Salaam city as shown in the previous discussion. There is an indication that effort to showcase Dar es Salaam city as sustainable city has not yielded the expected outcome. The process of formulating UA policy and/or including UA in the city master plan has taken longer time than expected. These delays have left the hapless urban farmers who are yet to be recognized officially by the city authorities with no alternative but to invade institutional and hazardous land leading to environmental degradation and insecurity of tenure.

The basic questions which remain to be answered could be: "Is there a possibility that UA will be formally recognized in the city?"; How long will the process to formalize UA take?"; "Who is holding back the process?"; "What is the current policy position on urban agricultural activities?”

\section{Methodology}

The paper is based on in-depth analysis of the content of the policies, published works and official reports with the intention of identifying the sources of delay in formalisation and incorporation of UA in the city's master plan. It critically analyse policies related to or which affects urban agriculture (UA) as a land use in Dar es Salaam city, Tanzania. The analysis seeks to uncover meanings and understandings of the broad interrelationships between policies and the practice of UA in the city. It compares specific provisions of the policies with the intention to identify their similarities and differences. In carrying out the analysis of the content of the policies, the paper adopts the hermeneutic approach [1012]. Gummesson [13] noted that hermeneutic approach uses a personal interpretive process in order to understand reality. The author states "language takes on a central role, qualitative assessments partially replace quantitative data, and general characteristics become lesser interest than specific features”. Jaspers [11] notes that, hermeneutic approach analyses and reflects upon texts 
and words in the need to uncover and find meaning. It can be used to criticise or support the content of a written word.

The paper identified specific provisions and articles within different policies which are meant to guide and manage urban agriculture in the city. It also evaluated published works and official reports which were directly associated to or reported on UA issues. Subjects of these various provisions articles and the content of the published research and official reports were critically analysed. The analysis was intended to single out the position, contribution, and impact of a specific instrument or report in the formalisation and inclusion of UA in the master plan. This intention guided the choice of the documents used in the analysis. The choice was based on the purposive convenient sampling (Kumar [14]). Documents which were pre-reviewed were chosen due to their rich information and ease of access or availability. The analysed policies include the Land Policy, 1995; Agricultural and Livestock Policy, 1997 and National Human Settlements Development Policy, 2000. The study also evaluated the impact of the content of the Town and Country Planning (Urban Farming) Regulations, 1992. In some instances the paper revised the content of official websites of key organisations such as government ministries and development programme.

One of the drawbacks of this method is the possibility of leaving a key document(s) that would otherwise provide more insight on the subject matter in case it was not within the reach of the researcher. Another possible challenge can be biasness related to interpretation of the text and words. The research addressed the two issues by (i) conducting of in-depth review of the existing literature, (ii) concisely define the objectives of the study and (iii) the paper was exposed to rigorous peer review after the initial drafts.

\section{What are the current policies positions regarding UA?}

Apart from the Town and Country Planning (Urban Farming) Regulations, 1992 there is no single explicit document for the management and regulation of the conduct of UA in Tanzania. Presently, UA is deemed to be regulated and managed using specific ministerial or sectorial policies and regulations as well as local government by-laws. Table 1 provides a summary of three policies and one regulation that has a direct impact in the operation of UA practice in Dar es Salaam. The list may not be exhaustive but it includes the key machineries which are intended to guide the orderly conduct of the UA practice.

It has been observed that three policies in Table 1 were promulgated to deal with other primary issues not urban agriculture. For example the National Land Policy, 1995 was intended to deal with general issues related to land management and administration. The Agricultural and Livestock policy of 1997 was intended to deal with broad agriculture and livestock development issues in the country. The National Human Settlements Development Policy, 2000 was intended to provide the orderly planning, management and regulation of human settlements developments. While dealing with these primary objectives, each of the policies found itself encompassing some provisions dealing with UA. The Town and Country Planning (Urban Farming) Regulations, 1992 explicitly deal 
with the conduct of UA in the country. It defines UA, set conditions and enumerates a number of activities that fall under it. The policies have been identified to include provisions which have an impact on UA in terms of tenure, land rights and the general conduct.

While these policies and regulations are country-wide; their scope of application in this paper has been delimited to Dar es Salaam city. In the following discussion, the paper analyses the similarities and differences within and between the selected three policies and later on, the regulations. The idea is to determine the positions of these policies towards UA in Dar es Salaam City.

Table 1: $\quad$ The summary of provisions in policies and regulations.

\begin{tabular}{|c|c|c|c|}
\hline $\begin{array}{c}\text { National Land Policy } \\
1995\end{array}$ & $\begin{array}{c}\text { Agricultural and } \\
\text { Livestock Policy, } 1997\end{array}$ & $\begin{array}{c}\text { National Human } \\
\text { Settlements Development } \\
\text { Policy, } 2000\end{array}$ & $\begin{array}{l}\text { The Town and } \\
\text { Country Planning } \\
\text { (Urban Farming) } \\
\text { Regulations, } 1992\end{array}$ \\
\hline $\begin{array}{l}\text { S. } 6.1 .2 \text { (i): Measures } \\
\text { to limit the loss of } \\
\text { agricultural land to } \\
\text { urban growth by } \\
\text { controlling lateral } \\
\text { expansion of all towns }\end{array}$ & \multirow{2}{*}{$\begin{array}{l}\text { S. } 3.3 .2 \text { (i) Agriculture } \\
\text { is not a principal } \\
\text { function of towns but } \\
\text { when properly } \\
\text { organized urban } \\
\text { agriculture has the } \\
\text { potential to provide } \\
\text { employment, income } \\
\text { and is a supplementary } \\
\text { source of food supply }\end{array}$} & $\begin{array}{l}\text { S.4.3.7.2(i) The } \\
\text { government shall } \\
\text { designate special areas } \\
\text { within planning areas } \\
\text { whereby people will be } \\
\text { granted legal rights to } \\
\text { engage themselves in } \\
\text { agricultural activities }\end{array}$ & $\begin{array}{l}\text { S. } 78.3(1) \text { : No person } \\
\text { shall occupy or use more } \\
\text { than three acres of land } \\
\text { for urban farming }\end{array}$ \\
\hline $\begin{array}{l}\text { S. 6.7.0(i): Agriculture } \\
\text { is not a principal } \\
\text { function of towns but } \\
\text { when properly } \\
\text { organized, urban } \\
\text { agriculture has the } \\
\text { potential to provide } \\
\text { employment, income, } \\
\text { and is a supplementary } \\
\text { source of food supply }\end{array}$ & & $\begin{array}{l}\text { S.4.3.7.2(ii) Continue to } \\
\text { regulate and research on } \\
\text { the conduct of urban } \\
\text { agriculture, this will } \\
\text { ensure that it does not } \\
\text { disrupt planned urban } \\
\text { development }\end{array}$ & $\begin{array}{l}\text { S.78.3 (2): No person } \\
\text { shall, except where that } \\
\text { person practices zero } \\
\text { grazing, graze his animal } \\
\text { in urban area }\end{array}$ \\
\hline $\begin{array}{l}\text { S. } 6.7 .0 \text { (ii): In their } \\
\text { present form } \\
\text { agricultural activities } \\
\text { often conflict with the } \\
\text { proper planning of } \\
\text { urban land uses }\end{array}$ & \multirow[t]{2}{*}{$\begin{array}{l}\text { S.3.3.2 (ii) The } \\
\text { government will } \\
\text { continue to regulate the } \\
\text { conduct of UA and will } \\
\text { ensure that it does not } \\
\text { disrupt planned urban } \\
\text { development }\end{array}$} & $\begin{array}{l}\text { S.4.3.7.2(iii) Review the } \\
\text { existing laws to facilitate } \\
\text { planned urban agriculture }\end{array}$ & \multirow{2}{*}{$\begin{array}{l}\text { S.78.4. From the date of } \\
\text { coming into effect of } \\
\text { these regulations, any } \\
\text { farming activity which } \\
\text { may be deemed to } \\
\text { constitute a nuisance in } \\
\text { the form of noise or } \\
\text { smell or pose a physical } \\
\text { danger to the safety of } \\
\text { the public shall not be } \\
\text { permitted in the areas } \\
\text { other than those zoned } \\
\text { for urban farming }\end{array}$} \\
\hline $\begin{array}{l}\text { S. 6.7.1: The } \\
\text { government will } \\
\text { continue to regulate the } \\
\text { conduct of urban } \\
\text { agriculture and will } \\
\text { ensure that it does not } \\
\text { disrupt planned urban } \\
\text { development }\end{array}$ & & $\begin{array}{l}\text { S.4.3.7.2(iv) Facilitate the } \\
\text { construction of } \\
\text { appropriate infrastructure } \\
\text { to mitigate/prevent land } \\
\text { degradation, water } \\
\text { pollution, and health and } \\
\text { safety hazards in the areas } \\
\text { whereby agriculture is } \\
\text { permitted }\end{array}$ & \\
\hline
\end{tabular}

The analysis has shown the existence of consensus and similarities between and within the policies in some aspects; not all. One of the agreements between the three policies is the idea that "UA has to be regulated in order to avoid its disruptions to planned urban development". This position has been explicitly stated under article 6.7.1 of the National Land Policy, 1995 article 3.3 .2 (ii) of the Agricultural and Livestock Policy, 1997 and article 4.3 .7 (ii) of the National Human Settlements Development Policy, 2000 as shown in Table 1. This 
statement suggests that; UA is a marginal land use which is not part of the planned urban development and likely to disrupt the important ones. This has been augmented by the National Land Policy which states that "In their present form agricultural activities often conflicts with the proper planning of urban land uses"

This interpretation is supported by the first part of the provisions in the National land Policy, 1995 and Agricultural and Livestock Policy that, "Agriculture is not a principle function of towns....But when properly organised UA has the potential to provide employment, income and is a supplementary source of food supply". Ideally, since UA is not a principle function of towns (urban areas) which is likely to disrupt or conflict with the planned land use, it has no need to claim a place within the towns and cities boundaries. It has to stay where it belong i.e. in the rural areas. With this type of policies driving the mindsets of the professionals and decision makers alike it has been difficult for UA to be accepted within towns or urban areas including the city of Dar es Salaam.

The preceding discussion has shown one of the two sides of the policies related to UA in Tanzania. The interpretation of the provisions has suggested that agriculture is less favoured compared to planned land uses in urban areas. However, in some instances these policies have shown a different stance. For example the second part of the provisions in the National land Policy, 1995 and Agricultural and Livestock Policy 1997 which states that, “....But when properly organised UA has the potential to provide employment, income and is a supplementary source of food supply" recognises the enormous contribution which can be made by UA to urban environment.

It comes with no wonder therefore, when the same National Land Policy, 1995 states under article 6.1.2 (i) it intentions "to devise measures which will limit the loss of agricultural land to urban growth by controlling lateral expansions of all towns". The provision not only recognises the contribution of UA to urban areas but also the need to ensure the availability of arable land by limiting other urban land uses. This article in a way contradicts with the other provisions within the same policy which were discussed earlier on with a stance that, agriculture is not a principle function of towns and it tends to disrupt other planned urban land uses. The need to set land aside for UA open up opportunities for discussion and its inclusion in the planned urban development. Conspicuously, this provision supports the existence of agriculture as a land use in urban areas.

It would appear that; this provision of the National Land Policy, 1995 was taken into consideration when formulating the National Human Settlements Development Policy in 2000. The 2000 policy has three statements all in favour of UA as follows:

(i) The government shall designate special areas within planning areas whereby people will be granted legal rights to engage themselves in agricultural activities.

(ii) The government intended to review the existing laws to facilitate planned UA. 
(iii) Government has an intention to facilitate the construction of appropriate infrastructure to mitigate/prevent land degradation, water pollution, and health and safety hazards in areas whereby agriculture is permitted.

If these provisions are taken to mean the government commitment towards $\mathrm{UA}$, then the future is promising. It shows that government has; on top of recognising the contribution of UA decided to embrace it in its urban areas by ensuring that farmers are allocated land which ensures security of tenure and even market of their produce. It also suggests that the government has identified the compatibility between UA and other planned urban developments in contrary to the position held in the National Land Policy, 1995 and Agricultural and Livestock Policy, 1997.

While the wording of the three statements is positive and promising the available evidence indicates that none of the three issues covered has been implemented. For example, Mkwela and Banyani [6] have shown that no agricultural land was set aside in the 20,000 Plot Delivery Project that was implemented between 2002/2003 to 2005/2006 in the Dar es Salaam city. The project acquired 76sq. km of land which was formerly used as agricultural land and converted it into a 37,000 residential plots. The consequence has been for the farmers to continue with agricultural activities in the buffer zones illegally (see figure 1). This serves as a warning that the mere policy commitment is not enough; there is a need to implement these provisions in fully when development projects are being designed.

The Town and Country Planning (Urban Farming) Regulations, 1992 is another instrument which has been developed to regulate the practice of UA in

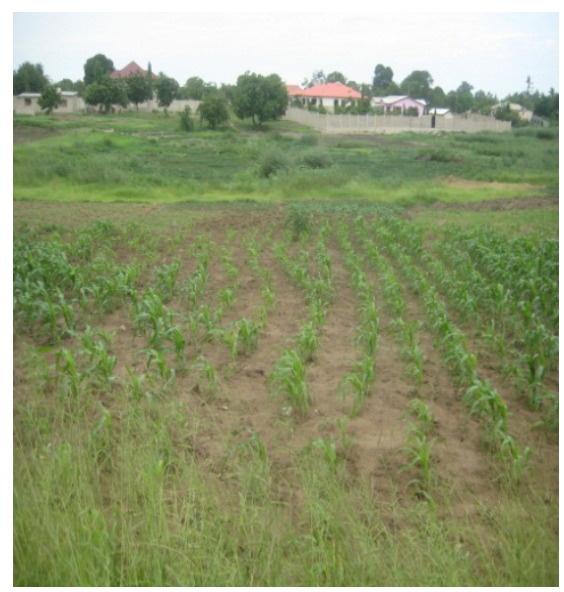

Figure 1: UA in the buffer zone of 20,000 plots delivery Mbweni area - Dar es Salaam.

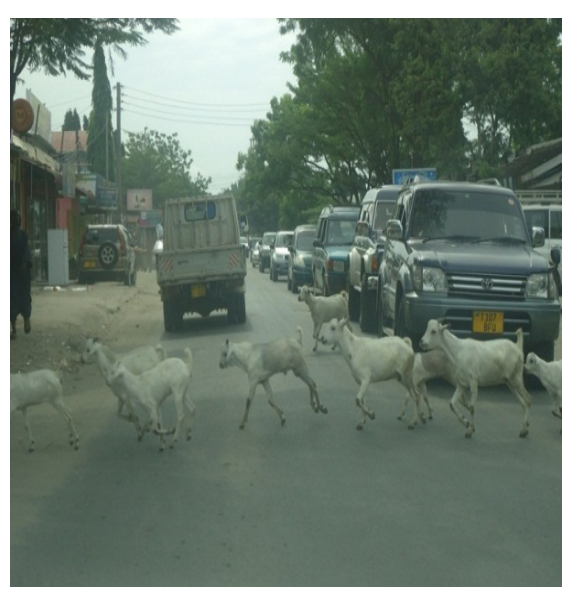

Figure 2: Herd of goats crossing the road, Kinondoni Dar es Salaam. 
urban areas. The regulations provide three conditions within which UA should be practised as shown in Table 1 . The regulations limits the acreage held for any urban farmer to 3 acres and restricts the livestock keeping to zero grazing. It also, restricts the carrying out of any agricultural activity that will be deemed to constitute a nuisance. While the provisions of the regulations are relatively good, they are seldom implemented. There are people legally holding land with more than 3 acres within the city that are put under agricultural use [4, 9]. Zero grazing has also proved to be difficulty; herds of goats can simply found roaming the city of Dar es Salaam and interferes with the traffic flow (see figure 2).

\section{Formalization of UA in Dar es Salaam city}

The discussion on the positions of policies which have direct impact on UA has revealed both, the support and opposition. However, the most recent policy, i.e. the National Human Settlements Policy, 2000 has more provisions which support the practising of UA and it even indicates the government intention to review other pieces of legislations in order to enable the practise to be planned. This forms part of the broad dream of UA in the city which is not as yet realised i.e. the possibility that the practice can be legitimised and incorporated in the city's master plan. The discussion below traces the various processes that had followed this dream.

Efforts to formalize UA in the city were initiated by the Sustainable City Programme in 1992. UNEP and UN HABITAT selected Dar es Salaam as one of the demonstration project for urban sustainability. A Sustainable City Programme (SCP) initiated in the 1990s was a response by UN Habitat to implement Agenda 21. The programme had an emphasis on strengthening the capacity of local city authorities in controlling environmental hazards and management of city resources in a sustainable way. Through its Sustainable Dar es Salaam Project (SDP) the project initiated the Environmental Planning Management (EPM) as a tool that involved various stakeholders to identify key environmental issues in the city. One of the urban environmental issues identified in Dar es Salaam was Urban Agriculture. A total of US \$5,615,000 was spent making the SDP the largest project of all SCP [5].

UA working group was created by the SDP consultation meetings to deal with UA issues in the city. The group composed of academic institutions, municipalities, ministries, financial institutions, urban citizens, informal and formal businesses, livestock owners and farmers met in 1993 [3]. The aim of the group was mainly to suggest ways of sustainable UA and to facilitate the inclusion of UA in the city's master plan. In 1993, the UA working group set out some strategies on how to improve the practice of UA; the group came up with three main ideas, integration of UA in the city master plan (A mixed land use strategy), preparation of the action plan, and implementation of demo projects. Out of these ideas, a UA demo project was successful launched [3].

The idea of mixed land use strategy and inclusion of UA in the city's master plan is further advanced by The Sustainable Cities International Network-Africa Programme (SCINAP). SCINAP is working with the local municipalities in Dar 
es Salaam city to formulate strategic plans on urban agriculture (SCINAP, 2011). The successful prepared strategic plans at the municipal level will be forwarded to the Ministry of Lands, Housing and Human Settlement Development (MLHHSD) for inclusion the city's 2010 to 2030 Master Plan. Due to the organizations commitment and collaboration with the municipalities, one of the three Dar es Salaam city's municipality has already formulated its strategic plans on urban agriculture and has been forwarded to the ministry for approval.

Demonstration projects are one of the ideas suggested by UA working group in Dar es Salaam under the SDP. One of a successful demo project is the Mbutu Agriculture Society (MAS) with 120 members. The project was registered in 1993; the main objectives of the project were to provide food security, encouraging gender equality and poverty alleviation activities. Other projects facilitating UA include Mikocheni vocational school gardening and composting project, The Kesho Trust and Kisiwani Environmental Group.

\section{Reflections}

The process to formalize and include UA in the city's master plan is faced with many challenges and takes longer than expected. The main questions posed earlier in this paper can be answered based on the in depth analysis of policies, regulations and efforts by local and international organization in the process of formalization and inclusion of UA in the city's master plan which has been discussed above. The main questions were, is there a possibility that UA will be formally recognized in the city? how long will the process to formalize UA take? Who is holding back the process? What is the current policy position on urban agricultural activities? Discussions below provide some reflections and way forward in regard to UA formalization in Dar es Salaam city.

\subsection{Is there a possibility of formalisation of UA in Dar es Salaam city?}

There is always a possibility and hope that UA will eventually be formalized in Dar es Salaam. However, ambiguous trends behind the process to include UA in the city's Master Plan reveal a major disregard of UA activities. Dar es Salaam city Municipalities are working on the Strategic Urban Development Plans (SUDP) that takes into consideration UA management. The plans will be forwarded to the Ministry of Lands and Human Settlement Development for approval and eventually inclusion in the city’s future Master Plan 2010-2030.

\subsection{How long will the process to formalize UA take to be finalised?}

The process looks simple and easy, however, the bureaucracy behind the process is frustrating. For over two decades, many local and international organizations in favour of UA have put their effort in persuading the decision makers to formally recognize UA with little success. It is not clear at this moment, how long will the process be finalized. 


\subsection{Who is holding back the process?}

Most of Dar es Salaam city residents have a negative attitude towards UA. People's perception on UA contributes to its drawback. City planners and law makers, realize the potential of UA to some of its residents, mainly, the jobless and the poor. However, agriculture is regarded as a rural activity and a disgrace of a proper urban planning. This attitude is hidden in the people's hearts and can only be manifested in the whole planning and decision making process regarding UA. People who could positively defend UA have a stigma that UA has no place in the city i.e. it is a shame, old fashioned, dirty, not proper, and uncivilized.

\subsection{What is the policy position on urban agricultural activities?}

The country as a whole does not have UA policy to guide the activity. At the moment UA is indirectly depicted by other National policies; as a result UA is not adequately represented. Further discussion on this item has been covered in section 3 of this paper.

\section{Conclusions}

The reality surrounding agriculture in Dar es Salaam city and many urban areas of the country is the same. UA in the city is considered as an informal activity at times a source of nuisance. Agriculture has been used as a short term strategy to cope with food shortages, economic, social, climatic and political instabilities that occur in different periods. Furthermore, UA is recognized by its importance in providing food security, employment and a source of income for urban residents, especially the poor. However, this recognition is not enough for the activity to be officially recognized and included in the city's long term plans. The dream of sustainable agricultural activities in the city will be uncertain, until the moment it will be formally recognized, regulated and supported by all stakeholders. From the analysis of the policies the following recommendations can be made:

- There is a need for a single policy document resulting from the harmonization of various policies related to or which affects UA activities in the city in order to realise an orderly conduct of the practice.

- Inclusion of UA in the master plan and other short term or ad-hoc city plans and projects.

- Educating the policy makers and the general public by emphasizing on the change of their attitude and perception regarding UA. More research on how much UA contributes to food security; employment and social economic stability need to be portrayed through exemplary projects. Initiation of a TV and early school programmes that promotes UA will also be important in changing people's perception and implanting good image of UA to children.

- The use of road reserves and way-leaves is recommended as a short term solution or strategy against scarcity of arable land. It is proposed that 
temporary licences be granted to co-operatives/peer or women groups/farmers groups to produce short cycle crops.

\section{References}

[1] Mougeot, L., Urban Agriculture: Definition, Presence, Potential and Risks, Main Policy Challenges. CFP Report No. 31.IDRC. Canada, 1999.

[2] Sawio, C., Managing urban agriculture in Dar es Salaam city, Cities Feeding People Initiatives, IDRC Canada, Report 20, 1998.

[3] Mwalukasa, M., Institutional aspects of urban agriculture in the city of Dar es salaam, Growing Cities, Growing Food, Urban Agriculture on the Policy Agenda, eds. N. Bakker., M, Dubbeling., S, Guendel., U, Koschella., H, de Zeeuw., RUAF: Netherlands, pp. 99-117, 2000.

[4] Mlambo, A., Institutionalizing urban agriculture in Dar es Salaam city through the EPM process Proc. Of the E-Conf. On Appropriate Methods for Urban Agriculture. Research, Policy development, Planning, Implementation and Evaluation, RUAF: Netherlands, pp. 1-10, 2002.

[5] Nnkya, T. The Sustainable Cities Programme in Tanzania 1992-2003: From a City Demonstration Project to a National Programme for Environmentally Sustainable Urban Development. UN HABITAT. NairobiKenya, 2004.

[6] Mkwela, H., Banyani, M., Urban Farming: A Sustainable Solution to Reduce Solid Waste Problems in Dar es Salaam, Tanzania. RICS publication. UK, 2008.

[7] Mlozi, M., Impacts of urban agriculture in Dar es Salaam, Tanzania. The Environmentalist, 17(2), pp. 115-124, 1997.

[8] Schmidt, S., Urban agriculture in Dar es Salaam, Tanzania. \#7-12, Food Policy for Developing Counties: Case studies, ed. P. Pinstrup-Andersen., F. Cheng., Cornell University, pp. 1-10, 2011.

[9] United Republic of Tanzania (URT), National sample census of agriculture 2002/2003, vol. vg Regional Report: Dar es Salaam region, Dar es Salaam, 2007.

[10] Ticehurst, G.W., Veal, A.J., Business Research Methods: A Managerial Approach, Longman Person Education Pty Limited, 1999.

[11] Jaspers, D., A Short Introduction to Hermeneutics, Westminster John Knox Press, Kentucky, 2004.

[12] Thiselton, A.C., Hermeneutics: An Introduction, Wm. Eerdmans Publishing, Michigan, 2009.

[13] Gummesson, E., Qualitative Methods in Management Research, Sage Publications Inc, Newbury Park, CA, 1991.

[14] Kumar R., Research Methodology: A Step by Step Guide for Beginners, London, Sage Publications, 1999.

\section{Policies and regulations}

United Republic of Tanzania (URT), The National Land Policy, 1995, www.tanzania.go.tz 
172 Sustainable Development and Planning VI

United Republic of Tanzania (URT), Agricultural and Livestock Policy, 1997, www.tanzania.go.tz

United Republic of Tanzania (URT), National Human Settlements Development Policy, 2000, www.tanzania.go.tz

The Town and Country Planning (Urban Farming) Regulations, 1992, http://faolex.fao.org/cgi-bin/faolex.exe.rec_id=005242 